\title{
FIGURATIVE CONSTITUENTS OF THE CONCEPT COLOR IN SPANISH AND UKRAINIAN (BASED ON FICTION TEXTS)
}

\author{
Ekaterina Lesnevskaya ${ }^{1}$
}

\begin{abstract}
The article features the results of a contrastive analysis of the figurative characteristics of color terms as elements of the conceptual worldview of Spaniards and Ukrainians. In this regard we consider the following topics: concept COLOR as a cross-object of conceptology, linguistic culture and discourse; color terms as an element of the conceptual worldview of Spaniards and Ukrainians; ethno-specific contrasts of the figurative constituents of the color terms black, white, red, blue, yellow, green in Spanish and Ukrainian in fiction. This study explores the linguocultural concept of COLOR from the cognitive, ethno-cultural and discursive perspectives, and therefore the concept can be considered as the subject matter of such disciplines as anthropology, linguocultural science and discourse theory. The corpus of the study was formed using the continuous sampling method from multi-genre prose written by contemporary Spanish (Carlos Ruiz Zafón, Camilo José Cela, Gabriel García Márquez) and Ukrainian (Yurii Andrukhovych, Lyubko Deresh, Oksana Zabuzhko) writers. A common feature of the color term black in Spanish and Ukrainian fiction is its use in the description of human blood and its altered states. The color terms black and white characterizing such concepts as NIGHT, DEATH, EYES can be observed in the individual authors' worldview of Spanish-speaking and Ukrainian writers despite the non-contiguous nature of the two languages and cultures. In the Spanish linguistic culture, the color term blue is used as an image of DEATH and LONELINESS, whereas in Ukrainian - as an image of RAGE, TENSION and ILLNESS.
\end{abstract}

\section{Keywords}

Contrastive analysis, color terms, conceptual worldview, Spanish, Ukrainian.

\section{Introduction.}

This paper provides a contrastive analysis of the figurative characteristics of color terms (rus. иветообозначениe, ger. Farbbezeichnung, sp. términos de color) as elements of the conceptual worldview of Spaniards and Ukrainians. In this regard we consider the following topics: (1) the concept COLOR as a cross-object of conceptology, linguistic culture and discourse; (2) color terms as an element of the conceptual worldview of Spaniards and Ukrainians; (3) ethno-specific contrasts of the figurative constituents of the color subconcepts NEGRO/ ЧОРНИЙ, ВLАNСО/БІЛИЙ, RОJО/.ЧЕРВОНИЙ, AZUL/CИНІЙ, VERDE/3ЕЛЕНИЙ, AMARILLO/ ЖОВТИЙ in Spanish and Ukrainian fiction texts.

\section{Background and motivations.}

2.1. The concept COLOR as a cross-object of conceptology, linguistic culture and discourse.

This study explores the linguo-cultural concept of COLOR from the cognitive, ethno-cultural and discursive perspectives, and therefore the concept can be considered as a cross-object of such disciplines as anthropology ${ }^{2}$, linguo-cultural science ${ }^{3}$ and discourse theory ${ }^{4}$.

\footnotetext{
1 Ekaterina Lesnevskaya, Senior Lecturer, National University "Odessa Law Academy", 23 Fontanskaya Doroga, Odessa, Ukraine, 65009, E-mail: katlev@ukr.net. ORCID ID: 0000-0003-0903-4170.

${ }^{2}$ MacLaury 2007

${ }^{3}$ Berlin 2000

${ }^{4}$ Chamizo\& Postigo 2008

${ }^{5}$ Forceville 2006

${ }^{6}$ Bishop 2007
}

The study of linguo-cultural concepts should take into account certain differences in the understanding of this concept in cognitive linguistics. For instance, from a cognitive point of view, the concept is «an operational unit of memory, mental lexicon, conceptual system and brain language (lingua mentalis), the whole worldview reflected in the human psyche» ${ }^{5}$. At the same time, the thesis on the preservation and structuring information about the world and oneself in the individual consciousness in the form of certain structures, notions, knowledge and judgments is rather important as well as the thesis on processing information from sensory signals at the input to mental representations of different types (images, propositions, frames, scripts, scenarios, etc.) in the human consciousness. Concepts and ideas are independent of language and only part of them receives language objectification, but the most important concepts are encoded in language 6 .

From the linguo-cultural viewpoint, researchers are interested in concepts that characterize the specific features of a culture as an aggregate of human achievements in all spheres of life as opposed to nature. When it comes to ethnic and social varieties of culture, cultural concepts, which represent collective meaningful mental formations recording the distinctiveness of the relevant culture become the units of the system of specific forms of behavior and activity - the value-saturated patterns of the worldview. Thus, in studies conducted from the standpoint of cognitive linguistics there is a movement from man to culture (linguistic and cognitive aspect), from the standpoint of linguo-cultural studies - from culture to man (linguocultural aspect) ${ }^{7}$. 
An important role in achieving a complete understanding of the character of verbalization of any linguo-cultural concept in any language is played by information on the semantics and etymology of the words nominating concept names, semantics of the figurative, associative meanings of the words representing concepts, context(s) in which words and phrases denoting and expressing the concept are used, cultural background of associations related to the concept, and set of value-labeled statements (proverbs, aphorisms, quotations) expressing certain concepts.

The main linguistic characteristic of the concept is that it is assigned to a certain way of language implementation. As it follows from the recognition of the concept as the content plan of the language sign, in addition to the subject (conceptual) and psychological (figurative and axiological) reference it includes all communicatively significant information: intra-systemic, pragmatic and etymological.

A distinctive feature of the concept as a unit of lexical semantics is its linguo-cultural significance. Singling out the linguo-cultural concept is a natural step in the formation of the anthropocentric paradigm of humanitarian knowledge. Essentially, the impersonal and objectivist understanding of the concept is authorized with respect to the ethnosemantic personality as the basic national and cultural prototype of the native speakers of this language recorded in the semantic system of the natural language, in the same way as impersonal modal judgments (probably) upon authorization relate to their subject (I suppose).

In the broadest sense, concepts include lexemes, the meanings of which constitute the content of the national language consciousness and form the "naive worldview" of native speakers of the language. The totality of such concepts forms the conceptosphere of the language ${ }^{8}$ in which the culture of the nation is concentrated. The determining factor in this approach is the way the world is conceptualized in lexical semantics, and the main research tool is the conceptual model used to single out the basic components of the concept semantics and reveal stable links between them.

In a narrower sense, concepts include semantic formations marked by their linguistic and cultural specifics and in one way or another characterizing the bearers of a certain culture - social, ethnic, professional, confessional, etc. The totality of such concepts does not form the conceptosphere as a certain integral

\footnotetext{
${ }^{7}$ Karasik 2009

${ }^{8}$ Pivtorak 2004

${ }^{9}$ Wierzbicka 2007

${ }^{10}$ Kulinskaja 2013

${ }^{11}$ Dedrick 1998

${ }^{12}$ Pichigina 2009

${ }^{13}$ Kapnina 2016, 22

${ }^{14}$ Kerttula 2002
}

and structured semantic space, but rather occupies a certain part of it - the conceptual area. Concepts can include only a limited number of semantic formations, which are essential for understanding the national mentality as a specific attitude to the world of its bearers. Metaphysical concepts (SOUL, TRUTH, LIBERTY, HONOR, LOVE) ${ }^{9}$ are mental essences of high or extreme abstractness; they refer to the invisible world of spiritual values, the meaning of which can be revealed only through a symbol - a sign that implies the use of its figurative subject matter content to express abstract content. Therefore, concepts of the latter type are synonymized with relative ease forming a conceptualized area where semantic associations are established between metaphysical meanings and the phenomena of the object world reflected in words, where spiritual and material cultures meet ${ }^{10}$.

Conceptual, figurative and axiological components can be singled out in the semantics of a concept as a multidimensional idealized form building. The figurative component objectifying cognitive metaphors through which abstract essences are comprehended in the linguistic consciousness is the most important for concepts denoting spiritual values of certain nations or ethnoses. The axiological component is not specific of metaphysical concepts; it is inherent in any mental formation referring to the spiritual life of man, as meaning is inherent in any cultural phenomena, with the loss of which, while maintaining their physical existence, they lose their cultural status. A direct consequence of the axiological nature of these mental units is their experiencedness - they are not only thought, but also emotionally experienced and are able to intensify the spiritual life of a person when they fall into the focus of thoughts or emotions ${ }^{11}$.

\subsection{Color terms as an element of the conceptu-} al worldview of Spaniards and Ukrainians.

In our study, we consider the content of the concept COLOR as a component of the color conceptosphere in the Spanish and Ukrainian linguistic cultures. It is important that the study of color terms in their basic, denotative meaning does not allow expressing the wealth of their stylistic and symbolic connotations ${ }^{12}$ At the same time, speaking of color as a concept, we consider not only its basic, primitive meaning, but also the whole system of additional connotations, concepts, associations, variations, which form a kind of semantic field reflecting the entire palette of shades of one neutral color, which, in fact, is a concept of a certain color ${ }^{13}$.

An important role in the study of color terms as an element of the conceptual worldview of different peoples is played by the symbolic function of color terms ${ }^{14}$ and their correct recognition by the bearers of these linguistic cultures, in our case - Spaniards and Ukrainians. Knowledge of color represents awareness of images canonized by world culture. Color marking and color symbol systems in different languages and cultures prove the influence of the 
mother tongue on the nature of the color-marking classification ${ }^{15}$. Analysis of color terms is necessary to identify the role of color in the formation of a person's visual space ${ }^{16}$ and the determinism of functioning in language given the cultural and historical traditions of different mentalities ${ }^{17}$.

The aesthetics of color originate in a person's imaginative perception of the surrounding reality. The transmission of information by means of color is based on emerging associations consisting of several layers: common natural layers and further layers - the influence of peoples' cultural traditions, e.g., Slavic traditions, to which a person belongs ${ }^{18}$, and color associations of personal experiences and impressions ${ }^{19}$. The color terms in Spanish and Ukrainian correlate with the semiotic, axiological and philosophical worldview. Considering the symbolism of color in the Spanish linguistic culture, we discover not only the phenomenon of color as a peculiar concept of a worldview that is different from Ukrainian, but also the system of color images embedded in the Spanish lexical base ${ }^{20}$.

Several factors influence the formation of the concept of a separately analyzed color: the frequency of the color term's use in speech, the sum of the main meanings intended by native speakers for a particular color term; and the presence/absence of a figurative connotation. The concept of color plays a special role in fiction. Here we are talking not so much about characteristics that are common for a certain ethnos, but about the individual author's perception of reality, which is embodied in his own artistic and imaginative worldview - the writer's individual style. Using certain color terms, a fiction author can more deeply convey the mood of the main characters, their emotions and feelings, indicate a conflict, etc.

\section{Methodology, corpus.}

Conceptual analysis in this study is carried out on various language corpora. As a rule, the analysis of different concepts in different languages is carried out using explanatory dictionaries, word formation dictionaries, phraseological units, epithets dictionaries,

\footnotetext{
${ }^{15}$ Bawej 2018

${ }^{16}$ Hardin 1997

${ }^{17}$ Rello 2007

${ }^{18}$ Gadányi 2000

${ }^{19}$ Ibáñez\& Zhu 2016

${ }^{20}$ Grossmann 1988

${ }^{21}$ Charčenko 2014

${ }^{22}$ Ruiz Zafón 2004

${ }^{23}$ Cela 1991

${ }^{24}$ García Márquez 2007

${ }^{25}$ Andruhovich 2018

${ }^{26}$ Andruhovich 2000

${ }^{27}$ Deresh 2010

${ }^{28}$ Zabuzhko 2003

${ }^{29}$ Zabuzhko 2014
}

proverbs and sayings dictionaries, etc. Proper account should be taken of the fact that when analyzing only lexicographical resources ${ }^{21}$, the understanding of the concept structure will not be complete and will be limited to the selection and description of its motivating and conceptual features. Figurative, axiological, symbolic and archaic features of a concept can be determined only based on observations of the text material.

With a view to conduct a contrastive analysis of the figurative constituents of the concept COLOR in the conceptual worldview of native Spanish and Ukrainian speakers and consider all the methods of its objectification in the language worldview, the corpus of the study was formed using the continuous sampling method from multi-genre prose written by contemporary Spanish (Carlos Ruiz Zafón («La sombra del viento») ${ }^{22}$, Camilo José Cela («La familia de Pascual Duarte») ${ }^{23}$, Gabriel García Márquez («Cien años de soledad») ${ }^{24}$ ) and Ukrainian (Yurii Andrukhovych («Lovers of Justice» ${ }^{25}$, «The Moscoviad» ${ }^{26}$ ), Lyubko Deresh («Intention!» ${ }^{27}$ ), Oksana Zabuzhko $\left(«\right.$ Sister, Sister ${ }^{28}$, «Girls $\left.\left.{ }^{29}\right)\right)$ writers.

With a view to perform a contrastive analysis of the figurative and axiological components of the concept COLOR/КОЛІР in the two languages, a sample of contexts was formed from the above corpus, in which words and phrases denoting and expressing color subconcepts are used. The sample consisted of 727 contexts, which were then distributed by language group and color subconcept as follows: (1) Spanish: (458/100\%): «negro» (130/28.4\%), «blanco» (100/ 21.8\%), «azul» (74/16.2\%), «rojo» (55/12\%), «amarillo» (48/10.5\%), «verde» $(29 / 6.3 \%)$, «rosa, Rosado» (9/2\%), «anaranjado» $(5 / 1.1 \%)$, «marron, moreno» (6/1.3\%), «violeto» $(2 / 0.4 \%)$; (2) Ukrainian; (269/100\%): «чорний» (70/26\%), «білий» (55/20.4\%), «червоний» $(40 / 14.9 \%)$, «синій» $(33 / 12.3 \%)$, «зелений» $(33 / 12.3 \%)$, «жовтий» $(31 / 11.5 \%)$, «коричневий» $(3 / 1.1 \%)$, «рожевий» (2/0.7\%), «фіолетовий» (2/0.7\%) (Fig. 1).

The conceptual, figurative and axiological components, the first of which is the determinative, are primarily singled out in the semantics of a concept as multidimensional idealized form building. The second most important component for the spiritual value concept is the figurative component, which objectifies cognitive metaphors in the language consciousness, through which abstract essences are comprehended. The axiological component is not specific of metaphysical concepts; it is inherent in any mental formation referring to the spiritual life of man, as meaning is inherent in any cultural phenomena, with the loss of which, while maintaining their physical existence, they lose their cultural status. A direct consequence of the axiological character of these mental units is their experiencedness - they are not only thought, but also emotionally experienced and are able to intensify the spiritual life of a person 


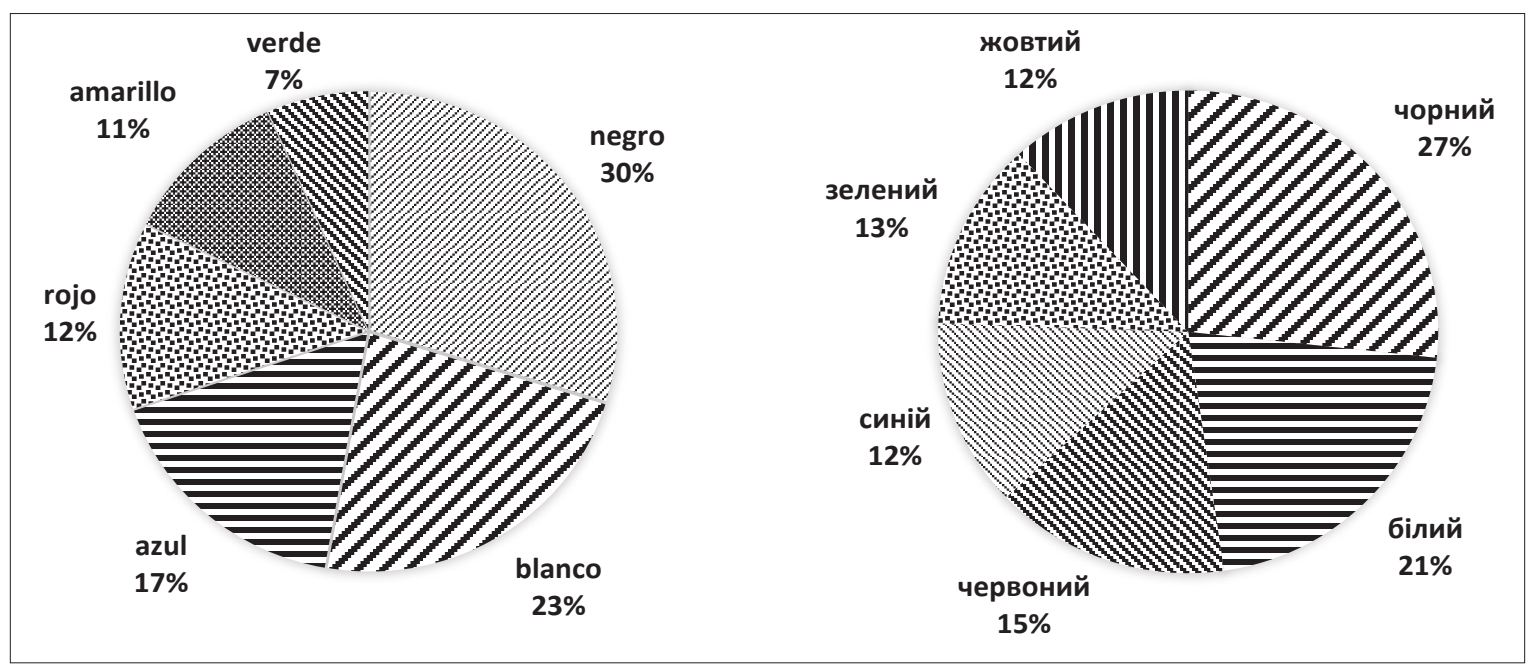

Fig. 1. Distribution diagrams of color subconcepts in Spanish and Ukrainian

when they fall into the focus of thought or emotion.

Conceptual analysis of color terms included information on the etymology of color designation (motivating constitution), basic and additional meanings (conceptual constitution), figurative, associative meanings, metaphors (figurative constitution), as well as cultural background and value-marked statements (proverbs, aphorisms, quotations (axiological constitution).

\section{Results and discussion.}

Color term NEGRO/ЧОРНИЙ, which is most frequent in the works of Spanish and Ukrainian authors (Sp. 28.4\% / Ukr. 26\%); it has a large number of similarities in the image systems of the two non-contiguous linguistic cultures. Common for the two linguistic cultures are the concepts of EYES, BLOOD, which are semantically based in the color term black.

For instance, in Spanish, the color term negro is used to describe (1) a person: hair («cabellera negra»), eyes («dos ojos negros y sin fondo», «sus ojos negrillos», «Tenía los ojos negros y sin expresión»), mustache («bigote negro») of a person; (2) things and objects: («chaqueta negra», «abrigo negro», «Como vestía siempre de negro», «pluma negra», «traje negro», «mantos de negrura impenetrable», «un sombrero grande y negro»), (3) tobacco products («tabaco negro»), (4) vehicles («automóvil negro», «coche negro»); (5) natural phenomena: shadows («la negra sombra»), streams of water («Un riachuelo de agua negra»), darkness («la escena fundió a negro»), nights («vi estrellas en la noche más negra de mi vida»).

In Spanish fiction texts, the color negro generally has negative semantics and is used in the following meanings: (1) «black = difficult, hard, heavy»: («vi estrellas en la noche más negra de mi vida/I saw stars in the darkest night of my life»); (2) »black = hot, smoky»: («cómo el alma maldita se le derramaba en

\footnotetext{
${ }^{30}$ Ruiz Zafon 2004
}

vapor y aliento negro que caía en lágrimas heladas sobre el espejo/as the cursed soul spilled out steam and black breath, which dropped in ice tears on the mirror»); (3) «black = gloomy»: («negras imaginaciones/black fantasies»).

Rhetorical figures of tautology («la negrura del apagón/blackness of obnubilation», «las mulatas vestidas de negro/mulattoes dressed in black», etc.) also increase the dominance of black, and numerous personifications ( «Cuando salí a la calle me pareció que la negrura se arrastraba por el empedrado/blackness plummeted along the pavement») and metonymic transfers ( «Se rumoreaba que Fumero liquidaba a notorios personajes por dinero, que despachaba figuras políticas por encargo de diversas manos negras (by order of various black hands) y que era la muerte personificada») kind of enliven it and emphasize the negative semantics of color.

The color term black is also the central element of the image of the Black Angel Zachariah («Zacarías el ángel ya no vestía de negro») in the novel «La sombra del viento» by Carlos Ruiz Zafón ${ }^{30}$, and in this case the semantics of black color loses its negative connotation: «Zacarías - a quien tomaba por emisario de los cielos, pues de negro o no, era un ángel luminoso - y el hombre más guapo que había visto/ Zacharias, who was taken by the emissary from heaven because whether black or not, he was a bright angel and the best man he had ever seen».

Often the color term black is in contrast with other colors, such as white, using the color antithesis black vs. white («La vi alejarse a través de las baldosas blancas y negras/saw her walk through black and white tiles»; «fotografías en blanco y negro/blackand-white photos», «un carruaje negro, de cortinajes velados, lo arrolló sin detenerse en plena luz del día/a black coach with curtains drawn passed without stopping in broad daylight»; «El mármol blanco estaba surcado por lágrimas negras de humedad/White marble was digested with damp black tears») comple- 
ments the contrast between feelings and the surrounding world emphasizing their colorlessness.

In the individual worldview of contemporary Ukrainian writers, the color term black is also used extensively to describe hair («чорнява Римочка Браверман 3 величезними просинцево-білими бантами в лиснючих косах»/black-haired Rimochka Braverman with huge white shiny bows in shiny braids; «чорне волосся / black hair»), eyes («не зводячи 3 Дарки отих загіпнотизованих очисьок, майже чорних од розширеної на всю райдужку зіниці /without taking those hypnotized eyes almost black from full iris pupils off Darka), things/objects: («чорні з позліткою бинди на вінках/black and gold bows on the wreath»), « піп у чорних ризах»/ priest in a black vestments» «з чорним прокопченим чайником»/with a black smoky teapot), drinks («був справжній чорний чай / it was real black tea»), vehicles («яку батьків шофер підвозив до школи службовою, так само лиснючою чорною Волгою/ who was brought to school by her father's chauffeur in an official shiny black Volga limousine); natural phenomena («наткнувся на чорну хмару/сате across a black cloud», «чорна поверхня води/ black surface of the water», «невидиме чорне небо/invisible black sky»), etc.

A common feature of the color term black in Spanish and Ukrainian fiction is its use in the description of human blood and its altered states (Sp. «Alcé la vista y vi el temporal derramarse como manchas de sangre negra entre las nubes /I looked up and saw the storm spill like spots of black blood among the clouds»); (Ukr.»кров охолола і перетворилася на густу чорну воду талої ріки/the blood cooled down and turned into thick black water of a melted river», «в чорних, масних згустках крови/in black, massive clusters of blood», «в чорно-кров'яних змивинах/in black-blooded rinses»).

A vivid example of the use of the color term black in the creation of images with negative semantics can be found, for example, in the novel by Yuri Andrukhovich «Moskoviada. A horror novel»" ${ }^{31}$, where the author compares the power of female charm with the power of a Black Orchid: «Тоді вона, так i не озирнувшись жодного разу, повільна, але слухняна, похиляється вперед. I це запрошення. Або виклик. Чорна орхідея впускає тебе/ Then she never looking back, slowly but obediently, leans forward. And this is an invitation. Or a challenge. The Black Orchid is letting you in»). The figurative component of black color is realized, on the one hand, through the concepts of CHARM, MAGNETISM, because black color always fascinates and attracts our attention, and on the other hand, the image of the Black Orchid refers to us with the concepts

\footnotetext{
${ }^{31}$ Andrukhovich 2000

${ }^{32}$ Zabuzhko 2014
}

of MYSTERY, ENIGMA, because the legend of the black orchid is widespread in different cultures. However, black pigment does not actually exist in pure form, and there are no absolutely black flowers in nature, so like the black tulip, the black orchid exists only in people's imagination. Thus, we can conclude about the creation of an additional conceptual antithesis MYTH VS. REALITY.

The second in terms of frequency of use in Spanish and Ukrainian fiction is the color term BLANCO/WHITE ((Sp. $21.8 \%$, Ukr. $20.4 \%)$. In Spanish and Ukrainian fiction, white color has both positive and negative semantics and is used in the description of clothing objects («vestido de alpaca blanca / white alpaca dress»; «la dama de blanco/lady in white», «las manos en el pecho blanco que todavía temblaban/ hands on the white chest that were still shaking»), eyes («Sus ojos blancos se alzaban hacia el techo/ His white eyes rose to the ceiling»), states of anxiety («Me quedé blanco/ I went white»), etc.

The color term white in Spanish is used in the following meanings: 1) «white = empty»: («Los ojos, blancos como cáscaras de huevo rotas / The eyes, white as broken egg shells»; «dos pilas de cuartillas, una en blanco y la otra escrita por ambas caras / two piles of pages, one in white (blank) and the other written on both sides); (2) «white = pure»: «Tomé un folio en blanco / I took a white (blank) sheet of paper); (3) «white = light»: ( «la gran esperanza blanca / great white hope»); (4) «white = dead»: («vi a mi mujer, blanca como una muerte» / I saw my wife, white as death) (5) «white=cold»; («La víctima recibió seis heridas de arma blanca en el vientre»/ The victim sustained six wounds in his mother's womb, caused by cold weapons)

In the individual authors' worldview of Ukrainian writers, the color term white is used together with the color term black creating bright contrasting images, for example, in the novel «Girls»" ${ }^{32}$ by Oksana Zabuzhko: «От тільки личка Наталя так i не розгледіла - його заступала місячно-бліда, колихка, мов розмита слізьми, пляма; взагалі, цілий сон був чорно-білий: чи то в нічному, чи в люмінесиентному освітленні» / But Natalia did not see the face - it was replaced by a moon-pale, colic, tear-blurred spot, the whole dream was black and white: whether in the night or in the luminescent light». Here we can trace the figurative antithesis in the form of contrasting colors, which creates the image of a black-and-white movie or a dream as a black-and-white movie. The emotional tension is also increased by the contrastive black night vs. white nightie («вона бачила його зі спини, кругом знову була ніч, і от $з$ тої ночі виступила йому назустріч маленька дівчинка в білій льолі і взяла його за руку / she saw him from behind, it was night again, and that night a little girl in a white nightie 
came forward and took his hand $\left.\rangle^{33}\right)$ and (2) white snow vs. black water («Вийшов із приміщення під сніг - біла ковдра тала у чорну воду/He went outside into the snow, the white blanket melting into black water» ${ }^{34}$ ).

The color term white is used in the individual author's worldview of Oksana Zabuzhko to convey human excitement («на пальцях, що стискали край лавочки, проступали білі плями суглобів/ white spots of joints were showing on the fingers that squeezed the edge of the bench»), purity and integrity of a woman («до тих найперших ревнощів і перших паскудств, стати стерильною, чистою й незворушною, як цей білий кахель, що ріже очі в електричному світлі / until the very first jealousy and first nasty things, to be sterile, clean and serene, like this white tile cutting the eye in electric light), color of the skin («у клубному піджаку видно буде опік од праски вище зап'ястя, на жовту суконку треба хоч трохи присмаглих плечей, а я ж тепер біла як сир / the club jacket will show iron burn above the wrist, to wear a yellow dress you need at least a little bit of tanned shoulders, and now I am white as cheese») ${ }^{35}$.

The color term ROJO/ЧЕРВОНИЙ denoting and expressing red rates third in the Ukrainian sample $(14.9 \%)$, whereas in Spanish this color is fourth in terms of frequency of use (12\%) and follows the blue color, which does not comply with the traditional notion of red being genuinely Spanish.

In the Spanish language, the core of the color conceptosphere is represented by the color term rojo, which means red. A synonymous variant of the lexeme rojo is the color term colorado, which means red and/or its reddish shade. The torero (bullfighter) uses a red cloth (muleta roja) during a bullfight (rojo as the symbol of blood). Reddish is also used in clothing and accessories (falda roja, flor roja en el pelo), dancers' outfits (bata de cola roja) (rojo as a symbol of passion, love, temperament). The color term rojo is quite common in Gabriel Garcia Marquez's novel «One Hundred Years of Solitude», especially to describe various bands («José Arcadio se amarró un trapo rojo en la cabeza/ José Arcadio tied $a$ red band on his head», «impuso a los hombres mayores de edad la obligación de usar un brazal rojo/imposed an obligation on men of legal age to wear a red arm-band»,, «suspendió el uso de los brazales rojos/suspended the use of the red arm-bands»), handkerchiefs («la cara tapada con un pañuelo rojo/ face covered with a red handkerchiefi), sweaters («la muchacha de suéter rojo/girl in

\footnotetext{
${ }^{33}$ Zabuzhko 2003

${ }^{34}$ Deresh 2010

${ }^{35}$ Zabuzhko 2003, 2014

${ }^{36}$ Zabuzhko 2014

${ }^{37}$ Ruiz Zafón 2004

${ }^{38}$ García Márquez 2007, 30
}

a red sweater»), and torture instruments («la sometían a vergonzosos tormentos con hierros al rojo vivo/ subjected her to shameful torments with red-hot irons»), sorcery («Creyendo que las rojas llantitas de caucho eran objetos de hechicería/Believing that the red rubber rims were objects of sorcery.), lights («con algunos focos rojos todavía encendidos/ with some red lights still on»)

In the works of both Spanish and Ukrainian authors, the color term red is used to denote emotional states: «коли ти влетіла в кухню, по очах тобі 3 розгону, навідлі (крупний план!) вдарило мамине мокре, червоне лице / when you rushed into the kitchen at full speed you ran into mom's wet red face in the foreground $»^{36}$, «rojo de rabia, subió al dormitorio/ red with rabies, she went up to the bedroom $\rangle^{37}$.

It is not uncommon for Spanish and Ukrainian authors to use the color term AZUL/СИНІЙ (Sp. 16.2\%, Ukr. 12.3\%) to create images of death and loneliness («cadáver que poco a poco se iba llenado de burbujas azules/corpse that little by little was filled with blue bubbles», «la calle desolada, bañada de luz azul y de frío/ the desolate street, bathed in blue light and cold») and descriptions of feelings such as tension, anger or illness («Обличчя вилискувало синюватою блідістю/His face flushed with a bluish pallor», «з синявою під очима/ with blue shadows under his eyes»).

A highly imaginative and symbolic function in Spanish and Ukrainian fiction is also performed by the color term AMARILLO/ЖОВТИИ (Sp. 10.5\%, Ukr. $11.5 \%$ ), which is associated with the concepts SUN and WARMTH that are common for the two linguistic cultures. This color, along with the color red, is the color of the Spanish flag, the symbolic meaning of which goes back to the legend about one of the kings of Aragon who, wishing to have his own flag, decided on a flag with a smooth gold field (yellow - gold), on which he ran two fingers, dropping them into a cup with fresh animal blood (red as the symbol of blood). The color term yellow is very eloquently represented in the works of Gabriel Garcia Marquez as a symbol of decay, old age, disease («caballitos amarillos del insomnio/ yellow horses of insomnia», «una anciana de una hermosura sobrenatural, con una amarillenta capa de armiño/an old woman of supernatural beauty, with a yellowish coat of ermine») ${ }^{38}$.

In turn, in the Ukrainian worldview, the main color terms are yellow and blue, which are the colors of the Ukrainian flag and symbols of wheat and the sky above. At the same time, Ukrainian fiction authors use yellow to create images of anger and hatred («злий жовтий колір/ angry yellow color», «Перед заплющеними очима Горича виникали жовті кола ненависті/ Before the closed eyes of Gorich there were yellow circles of hatred»).

The color term VERDE/3ЕЛЕНИЙ is also quite frequent in the works of Ukrainian and Spanish authors (Sp. 6.3\%, Ukr. 12.3\%). It is used on the 
one hand as an image of such positive concepts as spring («Отак от вони цілу зиму просодомили та прогоморили, а навесні дивимося: наше поле не зеленіс/ "So they sodomed and homorraed the whole winter and in the spring we look out: our field is not green», «Минули й Зелені Свята, а поле чорне, наче на ньому нічого й не сіяно/ Green holidays have passed, and the field is black, as if nothing has been sown on it»; "Добре, що можна так лежати у цій зеленій весняній воді/ It's good to lie in this green spring water»), youth («Ще мій сміх молодий і душа ще зелена/My laughter is still young and the soul is still green», "habia niños verdes/ there were green children»; and on the other hand as an image of negative concepts such as illness («Su piel verde revelaba una mala salud/ His green skin revealed bad health» $\left.{ }^{39}\right)$, weakness («Tenía las manos pálidas, con nervaduras verdes y dedos parasitarios/ His hands were pale, with green veins and parasitic fingers» $)^{40}$.

\section{Conclusions.}

The comparative analysis performed allows making important conclusions that the sequence of language representations of color symbols in the Spanish and Ukrainian linguistic cultures consists not only in the frequency of color terms black and white in the Spanish and Ukrainian linguistic cultures. The color terms black and white used to characterize such concepts as NIGHT, DEATH, and EYES can be observed in the individual authors' worldview of Spanish-speaking and Ukrainian writers despite the non-contiguous nature of the two languages and cultures. A common feature of the color term black in Spanish and Ukrainian fiction is its use in the description of human blood and its altered states. In the Spanish linguistic culture, the color term blue is used as an image of DEATH and LONELINESS, while in the Ukrainian - as an image of RAGE, TENSION and ILLNESS. A certain range of figurative parallels relates to the use of the color term yellow to denote such concepts as SUN and WARMTH.

\section{BIBLIOGRAPHY}

Андрухович Ю. Московіада. Роман жахів / Юрій Андрухович . - Івано-Франківськ : Лілея-НВ, 2000. - 152 с.

Андрухович Ю. Коханці Юстиції: роман / Юрій Андрухович. - Чернівці: Меридіан Черновіц, 2018.

Дереш Л. Намір! / Любко Дереш. - Х. : Клуб сімейного дозвілля, 2010 . - 272 с.

Забужко, О. Дівчатка /Оксана Забужко. Режим доступу : https://www.ukrlib.com.ua/books/printit.php?tid=4204

Забужко, О. Сестро, сестро : Повісті та оповідання /Оксана Забужко. - Київ : Факт, 2003. - 240 с.

Капнина Г. И., Коротяева И. Б. Концепт «цвет» в языковой картине мира // Филология и лингвистика. - 2016. - № 1. - С. 20-23.

Карасик В. И. Языковые ключи / В.И. Карсик. - М.: Гнозис, 2009. - 406 с.

Кулинская, С. Концепт «ЦВЕТ» и языковая личность/ С. Кулинская // Вестник краснодарского университета МВД России. - 2013. - №3 (21). - С. 84-87.

Півторак Л. Колоратив чорний у фразеології як вираження лінгвоментальності (на матеріалі іспанської, англійської, української та російської мов) / Л. Півторак // Культура народов Причерноморья. - 2004. - № 54. - С. 322-325.

Пичугина А. А. Символика цвета в валлийских сказаниях «Мабиногион». [Електронний ресурс]. - Режим доступа: ftp://lib. herzen.spb.ru/text/pichugina 92 208 215.pdf

Bawej, I. Kolorowy świat w odbiorze Polaków i Niemców w szerszym kontekście językowo-kulturowym/ Izabela Bawej. Bydgoszcz, Wydawnictwo Uniwersytetu Kazimierza Wielkiego, 2018. - 267 p.

Berlin, B. Basic color terms: their universality and evolution/ Brent Berlin. - London: Penguin. Stanford, Calif., CSLI Publications, 2000. - $196 \mathrm{p}$.

Bishop C. M. Neural networks for pattern and concept recognition / C.M. Bishop. - Oxford: Oxford University Press, 2007. - 482 p.

Cela, C. J. La familia de Pascal Duarte/Camilo José Cela. - Barcelona: Ed. Destino, 1991. - 164 p.

Chamizo, P. J., Postigo, E. Los términos de color como falsos amigos: Algunas consideraciones en caso del inglés y español / Pedro José Chamizo, Encarnación Postigo // Lengua y culturaю - 2008. - P. 79-85.

Charčenko, V. Bol’šoj slovar' cvetooboznačenij russkogo jazyka: svyše 6000 slov v 12000 kontekstach/ Vera Charčenko. - Schöneiche bei Berlin, Plaksina, 2014. - 412 p.

Dedrick, D. Naming the rainbow: colour language, colour science, and culture/ Don Dedrick. - Dordrecht [u.a.]: Kluwer, 1998. - 215 p.

Forceville Ch. Non-verbal and multimodal metaphor in a cognitive framework: Agendas for research/ Ch. Forceville // Cognitive Linguistics: Current Applications and Future Perspectives: [eds. Kristiansen G., Archard M., Dirven R., Ruiz de Mendoza Ibáñes F.J.]. - Berlin; New York: Mouton de Gruyter, 2006. - P. 379-402.

Gadányi, K. (2000). Slovo i cvet v slavjanskich jazykach/ Károly Gadányi. - Melbourne: Acad. Press, $2000 .-252$ p.

García Márquez, G. Cien años de soledad/Gabriel García Márquez. - Madrid: Real Acad. Española, 2007. - 609 p.

Grossmann, M. Colori e lessico: studi sulla struttura semantica degli aggetivi di colore in catalano, castigliano, italiano, romeno, latino ed ungherese / Maria Grossmann. - Tübingen: Narr, 1988. - 413 p.

Hardin, C.L. Color categories in thought and language/ Clyde L. Hardin. - Cambridge [u.a.]: Cambridge Univ. Press, 1997. - 404 p. Ibáñez, Ma Azucena Penas, Zhu, Wen (2016) Análisis de los términos léxicos y traductológicos básicos de color en español y en chino. Hipótesis fisiológica y comprobación lingüística. [Електронний pecyрс]. - Режим доступу: https://dialnet.unirioja.es/descarga/articulo/6193362.pdf

Kerttula, Seija English colour terms: etymology, chronology, and relative basicness / Seija Kerttula. - Helsinki: Soc. Néophilologique, 2002. -364 p.

MacLaury, R. E. Anthropology of color: interdisciplinary multilevel modeling / Robert E..MacLaury, - Amsterdam: Benjamins, 2007. -485 p.

\footnotetext{
${ }^{39}$ García Márquez 2007, 28

${ }^{40}$ García Márquez 2007, 241
} 
Rello, L. Términos de color en español: semántica, morfología y análisis lexicográfico. Definiciones y matices semánticos de sus afijos / Luz Rello. [Електронний ресурс]. - Режим доступу: http://www.dialogodelalengua.com/articulo/pdf/5_rello_colores_dl.pdf Ruiz Zafón, C. La sombra del viento/ CarlosRuiz Zafón. Barcelona, Planeta, 2004. - 575 p.

Wierzbicka, A. Słowa klucze: różne języki - różne kultury. - Warszawa, Wydawn Uniw. Warszawskiego, 2007. - 563 p.

\section{REFERENCES}

Andruhovich, Ju. (2000). Moskoviada. Roman zhahiv [Московіада. Роман жахів]. Ivano-Frankivs'k: Lileja-NV.

Andruhovich, Ju. (2018). Kohanci Justiciї [Коханці Юстиціï]. Chernivci: Meridian Chernovic.

Bawej, I. (2018). Kolorowy świat w odbiorze Polaków i Niemców w szerszym kontekście językowo-kulturowym. Bydgoszcz:

Wydawnictwo Uniwersytetu Kazimierza Wielkiego.

Berlin, B. (2000). Basic color terms: their universality and evolution. London: Penguin. Stanford, Calif., CSLI Publications.

Bishop, C. M. (2007). Neural networks for pattern and concept recognition. Oxford: Oxford University Press.

Cela, C. J. (1991). La familia de Pascal Duarte. Barcelona: Ed. Destino.

Chamizo, P. J, Postigo, E. (2008). Los términos de color como falsos amigos: Algunas consideraciones en caso del Inglés y Español, Lengua y cultura, pp.79-85.

Charčenko, V. (2014). Bol’šoj slovar' cvetooboznačenij russkogo jazyka: svyše 6000 slov v 12000 kontekstach. Schöneiche bei Berlin: Plaksina. Dedrick, D. (1998). Naming the rainbow: colour language, colour science, and culture. Dordrecht [u.a.]: Kluwer.

Deresh, L. (2010). Namir! [Намip!]. H. : Klub simejnogo dozvillja.

Forceville Ch. (2006). Non-verbal and multimodal metaphor in a cognitive framework: Agendas for research. In: eds. Kristiansen G., Archard M., Dirven R., Ruiz de Mendoza Ibáñes F.J.], Cognitive Linguistics: Current Applications and Future Perspectives. Berlin;

New York: Mouton de Gruyter, pp. 379-402.

Gadányi, K. (2000). Slovo i cvet v slavjanskich jazykach. Melbourne: Acad. Press.

García Márquez, G. (2007). Cien años de soledad/ Gabriel García Márquez. Madrid: Real Acad. Española.

Grossmann, M. (1988). Colori e lessico: studi sulla struttura semantica degli aggetivi di colore in catalano, castigliano, italiano, romeno, latino ed ungherese. Tübingen, Narr.

Hardin, Clyde L. (1997). Color categories in thought and language. Cambridge [u.a.]: Cambridge Univ. Press.

Ibáñez, M. A. P., Zhu, W. (2016). Análisis de los términos léxicos y traductológicos básicos de color en Español y en Chino. Hipótesis fisiológica y comprobación lingüística. https://dialnet.unirioja.es/descarga/articulo/6193362.pdf

Kapnina G. I., Korotjaeva I. B. (2016) Koncept «cvet» v jazykovoj kartine mira, Filologija i lingvistika, 1, pp. $20-23$.

Karasik, V. I. (2009). Jazykovye kljuchi [Языковые ключи]. Moscow: Gnozis.

Kerttula, S. (2002). English colour terms: etymology, chronology, and relative basicness. Helsinki: Soc. Néophilologique.

Kulinskaja, S. (2013). Koncept «CVET» i jazykovaja lichnost' [Концепт «цвет» в языковой картине мира], Vestnik krasnodarskogo universiteta MVD Rossii, №3 (21), pp. 84-87.

MacLaury, R. E. (2007). Anthropology of color: interdisciplinary multilevel modeling. Amsterdam: Benjamins.

Pichugina, A. (2009). Simvolika cveta v vallijskih skazanijah «Mabinogion» [Символика цвета в валлийских сказаниях «Мабиногион»]. ftp://lib.herzen.spb.ru/text/pichugina_92_208_215.pdf

Pivtorak L. (2004). Kolorativ chornij u frazeologiï jak virazhennja lingvomental'nosti (na materiali ispans'koï, anglijs'koï, ukraïns'koï ta rosijs'koï mov) [Колоратив чорний у фразеології як вираження лінгвоментальності (на матеріалі іспанської, англійської, української та російської мов), Kul'tura narodov Prichernomor'ja, № 54, pp. 322-325.

Rello, L. (2007). Términos de color en español: semántica, morfología y análisis lexicográfico. Definiciones y matices semánticos de sus afijos. http://www.dialogodelalengua.com/articulo/pdf/5_rello_colores_dl.pdf

Ruiz Zafón, C. (2004). La sombra del viento. Barcelona: Planeta.

Wierzbicka, A. (2007). Słowa klucze: różne języki - różne kultury. Warszawa: Wydawn Uniw. Warszawskiego.

Zabuzhko, O. (2003). Sestro, sestro : Povisti ta opovidannjaju [Сестро, сестро : Повісті та оповідання]. Куіv: Fakt.

Zabuzhko, O. (2014). Divchatka [Дівчатка]. https://www.ukrlib.com.ua/books/printit.php?tid=4204

\section{Анотація}

У статті наведені результати порівняльного аналізу образних характеристик колоронімів як елементів концептуального світогляду іспанців та українців. У зв'язку з цим розглянуто наступні теми: (1) концепт КОЛІР як крос-об'єкт концептології, мовної культури та дискурсу; (2) колороніми як елементи концептуального світогляду іспанців і українців; (3) етноспецифічні образні складові кольорових субконцептів negro/чорний, blanco/білий, rojo/.червоний, аzul/синій, verde/зелений, amarillo/жовтий іспанською та українською мовами в художньому тексті. Корпус дослідження сформовано з використанням методу суцільної вибірки з багатожанрової прози сучасних іспаномовних (Карлос Руїс Сафон, Каміло Хосе Села, Габрієль Гарсія Маркес) та україномовними (Юрій Андрухович, Любко Дереш, Оксана Забужко) письменниками. Спільним для двох лінгвокультур є використання колороніму negro/чорний в індивідуально-авторських картинах світу для опису людської крові та іiї змінених станів. Кольорові контрастні пари negro/чорний vs. blanco/білий, що характеризують образний чинник таких концептів, як НОЧЬ, СМЕРТЬ та ОЧІ, $є$ також спільними для іспаномовних та українських письменників, незважаючи на неблизько спорідненість двох мов і культур, тоді як символіка колороніму аzul/синій $€$ контрастною в досліджуваних художніх дискурсах: в іспаномовних текстах колоронім синій використується письменниками у формі метафоричних образів-концептів СМЕРТЬ і САМОТНІСТЬ, а в українській лінгвокультурі - концептів ГНІВ, НАПРУГА, ХВОРОБА.

\section{Ключові слова}

Контрастивний аналіз, колороніми, концептуальна картина світу, іспанська, українська. 